\title{
A Genre Analysis of English and Chinese Legal Research Article Abstracts: A Corpus-based Approach
}

\author{
Jing Duan \\ School of Foreign Languages, Southwest University of Political Science and Law, Chongqing, China \\ Jing Wei \\ College of International Studies, Southwest University, Chongqing, China
}

\begin{abstract}
Research article (RA) abstracts are generally viewed as the gateway to know the gist and major findings of a study. They also function as a "promotional" genre to attract readers' interest and increase readership so as to better engage the authors in the academic communities. Although RA abstracts as a genre have been gaining more attention over the years, there is still a lack of study on RA abstracts in the field of law, let alone cross-linguistic study concerning them. Therefore, this study investigates English and Chinese legal RA abstracts from the perspective of genre, analyzes their move structures, frequency and features, and then compares the similarities and differences of them in two different languages. To this end, a corpus consisting of 60 RA abstracts was compiled, 30 randomly selected from three prestigious English law journals and 30 from three Chinese law journals. The move analysis was conducted based on an adjusted model of four moves. The results reveal that the moves of Introduction, Gap-filling and Contribution are obligatory while that of Methodology is optional in both languages. However, English abstracts, with more complicated move structures than Chinese ones, tend to state explicitly the purposes of study while Chinese abstracts show a preference for pointing out the "Gap" first.
\end{abstract}

Index Terms-legal RA abstracts, genre, move analysis, move structure

\section{INTRODUCTION}

Over the past years, research articles (hereinafter referred to as RAs) have received great interest and attention of academic investigations from genre and discourse analysts as RAs push forward professional development, enhance discourse community membership and facilitate international academic exchanges. Abstracts, as the first step to attract readers' attention and present the writer's credibility to address the topic as an insider, are extremely important in presenting and even marketing one's work to the academic world. A qualified abstract must serve certain communicative purposes identified by the professional community so that the parent paper stands a better chance to attract attention and get published.

Representative genre explorations of abstracts include those in the fields of language and linguistic studies (Santos, 1996; Lorés, 2004; Pho, 2008; Tseng, 2011; Doró, 2013), psychology (Hartley, 2003), engineering, physics, marketing, sociology and humanities (Hyland, 2004), protozoology (Cross \& Oppenheim, 2006), literature (Tankó, 2017; Zhao, Liu, Deng et al.), humanities, social sciences and natural sciences (Stotesbury, 2003) and medicine (Salager-Meyer, 1990, 1992; Chu \& Jiang, 2018). There are also some studies concerning cross-disciplinary perspectives such as applied linguistics and medicine (Cavalieri, 2014), law and business (Hatzitheodorou, 2014). As English is the dominant language on the international academic stage, it has always been the focus of RA studies. Thus there are also some cross-linguistic investigations like English and Spanish (Martín-Martín, 2003); Italian and English (Diani, 2014), French and English (van Bonn \& Swales, 2007), etc.; and cross-cultural explorations including those between Iranian and English (Majid \& Omid, 2018), Chinese and English (Cao \& Xiao, 2013), etc. It is shown that abstracts across different disciplines and cultures adopt different move patterns with different characteristics. Diversified and numerous as the studies are, little attention has been paid to RA abstracts in the field of law. This study conducts a comparative genre analysis of English and Chinese legal research article abstracts to investigate their rhetorical move structures and explore the similarities and differences, aiming to promote understanding of RA abstracts in the field of law across the two languages and shed some pedagogical light on ESP and EAP teaching for non-native writers at tertiary level.

\section{LITERATURE REVIEW}

\section{A. Research Article Abstracts as a Specific Genre}

The studies on "genre" and "genre analysis" have gone through decades of development. There are mainly three approaches towards it. First is the systemic functional linguistics approach, viewing genre as the result of "register and 
goals". Hasan (1977) defined genre as "a type of discourse" in her description of contextual configuration (CC) and generic structure potential (GSP), which classified which elements were obligatory and which were optional. Halliday (1978) included genre in his discussion of register: "The field, tenor and mode act collectively as determinants of the text through their specification of the register." Martin (1992) viewed genres as a social interactional process concerning how things got done, which were realized through registers and registers in turn were realized through language. Second is the new rhetorical approach. Representative figures include Bazerman, Myers and Miller. They see genre as dynamic and social action in which context of the situation is involved. Situational contexts and communicative purposes must be considered together when analyzing a genre (Miller, 1984). The third is the ESP approach and also the prevailing one in contemporary studies. As Swales (1990) saw it, genre was a class of communicative events that share some certain sets of communicative purposes recognized by certain specific communities. Swales and Feak (2009) further defined genre as "a type of text or discourse designed to achieve a set of communicative purposes". Another key figure Bhatia (2004) referred to genre as "language use in a conventionalized communicative setting in order to give expression to a specific set of communicative goals of a disciplinary or social institution, which give rise to stable structural forms by imposing constraints on the use of lexico-grammatical as well as discoursal resources". Their emphasis on "communicative purposes or goals" have influenced many scholars and provided inspirations on research in different fields.

The past decades have seen increasing interest and attention to the notion of genre and its application in language teaching and learning. Abstracts have long been studied as a recognizable kind of genre that functions as "independent genres as a mandatory source of consultation for researchers" (Van Dijk, 1980), "representation" (Bazerman, 1984), or significant carriers of a discipline's epistemological and social assumptions (Hyland, 2000). The essence of this genre is one of distillation (Swales, 1990), "a description or factual summary of the much longer report" (Bhatia, 1993) or "condensed document representation" (Cross \& Oppenheim, 2006). By resorting to certain linguistic and rhetorical practices in abstracts, academics demonstrate their professional credibility and the value of their work to the discipline (Hyland, 2000). Apart from summarizing or representing the related articles, abstracts have another unique aim-to attract interest in a time of busy readership and persuade people into reading the whole articles. There is no doubt that, RA abstracts, with the limited space and word count, involves a certain "marketisation" - a promotion of oneself and one's paper through discursive means which might be considered analogous to the promotion of goods (Fairclough, 1995); and they also projects a specific disciplinary context to situate themselves in it and a way of conducting social relations with colleagues (Hyland, 2000). So the authors of abstracts at least want to 1) persuade the editors that their work is important enough to be published; 2) arouse readers' interest and urge them to read on; 3) inform readers of the main content and findings of the paper; 4) promote the study and demonstrate their membership, competence, and credibility in the target discourse or academic community. Based on Halliday's (1994) theory of metafunctions, the content of abstracts relates to the ideational metafunction; the generic structure resorts to textual metafunction and the purposes of authors reflect interpersonal metafunction. Therefore, abstracts, as a genre, are informative with a marketing aim. It is important and meaningful to analyze the generic structures of abstracts and their linguistic realizations so as to find out how those communicative purposes are achieved.

\section{B. Move Analysis of RA Abstracts}

According to Swales \& Feak (2009), a move is a stretch of text with a definable rhetorical function, which is realized by smaller conventional and optional discourse units in specific genres. Such units are called "steps" (Swales, 1990; Santos, 2002; Hyland, 2004), "sub-moves" (Nwogu, 1991; Santos, 1996) or "rhetorical strategies" (Bhatia, 1993; Martín-Martín, 2003). Like other genres, abstracts display a relatively stable generic template to help authors accomplish their academic and interpersonal goals. Previous studies show that abstracts in different professional fields adopt different patterns of moves. Thus we can see different models have sought to delineate the textual organizations of RA abstracts in terms of moves. Hyland (2000), after rigorous analysis and research of 800 RA abstracts taken from both soft and hard sciences including philosophy, applied linguistics, sociology, physics, marketing, electrical engineering, mechanical engineering and biology, proposed a five-move model (Introduction-Purpose-Method-Product-Conclusion) to investigate RA abstracts. He concluded that RA abstracts in hard sciences and soft sciences bore a lot of differences (For example, writers in the soft knowledge domains see a greater need to situate and contextualize their discourse with an Introduction, while writers in the hard knowledge fields tend to omit this move in favor of a description of the Method.) and writers needed to establish their credibility and status of being an insider of the academic community through the regular patterns of abstracts. Saboori and Hashemi (2013), using Hyland's model, studied the rhetorical structure, voice and tense of the verbs and self-mentioning of the author in RA abstracts across three different fields of applied linguistics, applied economics and mechanical engineering. They found that the move least frequently used was Introduction. Majid and Omid (2018) did a cross-cultural study on the RA abstracts of agricultural engineering based on Hyland's model and found out Iranian and native scholars were significantly different in using the moves of Introduction and Method. Bhatia (1993) proposed a four-move model including "introducing the purpose", "describing the method", "summarizing the results" and "presenting the conclusions". Alhuqbani (2013) used Bhatia's model and Hyland's model to study the rhetorical structures of abstracts across four unrelated disciplines in Arabic: law, linguistics, medicine and police, concluding that Arabian medicine abstracts strictly adhered to either model while the other three had no conventional move structure. 
Another influential model is the famous Swalesian model (1990) of CARS (Creating a Research Space for analyzing introductions of RAs) and IMRD model (Introduction-Methods-Results-Discussion). Lorés (2004), by analyzing 36 RA abstracts from linguistics based on these two models, found out the abstracts demonstrated the three types of IMRD structure, CARS structure and a combinatory structure, fulfilling three different functions, namely, the informative, indicative and informative-indicative functions. Marefat and Mohammadzadeh (2013) also conducted research under these two models, investigating literature RA abstracts written in English and Persian. Their results were not consistent with Lorés' claims and showed that none of the models were efficient though literature abstracts matched CARS more.

Santos (1996) examined the abstracts of RAs in applied linguistics at the macrolevel of textual organization and content as well as at the microlevel of textual analysis and probably was the first to report a five-move pattern in this arena: M1-situating the research, M2-presenting the research, M3-describing the methodology, M4-summarizing the results, M5-discussing the research. Tseng (2011) extended Santos' work and studied the length and verb tenses of each move in the same field. Cross \& Oppenheim (2006), inspired by Santos' model, studied the semantic organization and thematic structure of 12 abstracts in the field of protozoology from CABI database. They aimed to provide some practical implications for information retrieval like abstracting and indexing services instead of for pedagogical purposes, which interestingly displayed another important application area of genre analysis. Doró (2013) did cross-disciplinary analyses on abstracts of linguistics and literature based on Santos' five-move pattern, revealing that linguistics abstracts provided clearer reference to the research scope, methodology and results while literature abstracts emphasized placing the research into a wider context and offering tentative reference to the findings.

Apart from linguistics, literature abstracts have also received much attention. A model that is worth noting is one compiled by Tankó (2017), who analyzed 135 literary RA abstracts from four influential international journals and presented the move structure model for LRA abstracts: Topic-Background-Niche-Purpose-Method-Outcome-Conclusion-Implications. After careful examination of the syntactic complexity and lexical richness of LRA abstracts with soft-ware driven analysis, Tankó concluded that LRA abstracts had high syntactic complexity and lexical density, making them different to comprehend. Zhao, Liu, Deng et al. (2019) proposed their move pattern (Background-Purpose-Conclusion-Implication) based on the studies of Swales (1990), Santos (1996), Stotesbury (2003) and Tankó (2017) and furthered Tankó’s study in the literature field.

Judging from the previous models, it can be seen that most genre analysis models put emphasis on the "academic" or "summarizing" aspects of RA abstracts. This study believes that equal attention should be paid to the "marketisation" or "promotion" aspect when constructing a RA abstract since abstracts, to a large degree, also aim at attracting readers to finish reading the whole paper and convincing them that the study is important in the academic field. Based on this, this study proposes an independent move of "Gap-filling", where gaps or problems in existing literature are presented so as to provoke readers' interest and thinking, serving the communicative purpose of "marketisation". However, most previous studies (except the "Niche" move in Tankó's study) have included this "problem-raising" part in the "Introduction" or "Background" move. This study believes it is necessary to separate "Introduction" move and "Gap-filling" move.

Moreover, studies on the abstracts of legal RAs seem quite rare over the past decades. Most of the attention has been put on non-academic contexts. For example, Bhatia (1993; 2008) distinguished between linear move-structure and interactive move-structure in the research of legislative provisions and legal cases and investigated international arbitration discourses. In academic contexts, very limited literature is found: From a cross-disciplinary perspective, Hatzitheodorou (2014) proposed an adapted framework drawing on those of Swales (1990), Lewin, Fine \& Young (2001), Pho (2008) and Agathopoulou (2009), and analyzed RA abstracts in the field of law and business. She found that business abstracts displayed a higher frequency of moves than law abstracts and had a tendency for more extended texts. Ghasempour and Farnia (2017), based on Hyland's (2000) and Tseng's (2011) models, attempted a cross-linguistic study on Persian and English legal RA abstracts. Their findings showed that the moves of purpose, method and conclusion were more frequently used in English abstracts while those of introduction, purpose and conclusion were more frequent in Persian abstracts. To the best of the author's knowledge, there has not been comparative study on the English and Chinese legal RA abstracts so far. Therefore, the present study aims to fill this gap in order to advance research in the academic discourse community of law with the following research questions to be addressed:

1. What moves occur in English and Chinese legal RA abstracts and what are their frequencies in the two languages respectively?

2. What are the features and functions of the moves?

3. What are the move structures of English and Chinese legal RA abstracts and what are their similarities and differences?

\section{METHODOLOGY}

\section{A. The Corpus}

The corpus of the present study consists of 60 RA abstracts randomly selected from six prestigious English and Chinese legal journals. 30 Chinese abstracts were selected from China Legal Science, Chinese Journal of Law and Peking University Law Journal (ten abstracts from each journal), and 30 English abstracts from Harvard Law Review, 
The Yale Law Journal and Columbia Law Review (ten abstracts from each journal). The time span covered by those abstracts was 2018-2019 to ensure they demonstrated the latest trend in legal RA abstract writing. Some details of the corpus are presented in Table 1 (the statistics are derived from the software Wordsmith):

TABLE 1

LEGAL RAABSTRACTS CORPUS

\begin{tabular}{|c|c|c|c|c|}
\hline Language & Journal & Tokens & Types & STTR \\
\hline \multirow{3}{*}{ English } & Harvard Law Review (10) & \multirow{3}{*}{8186} & \multirow{3}{*}{2300} & \multirow{3}{*}{48.09} \\
\hline & The Yale Law Journal (10) & & & \\
\hline & Columbia Law Review (10) & & & \\
\hline \multirow{3}{*}{ Chinese } & China Legal Science(10) & \multirow{3}{*}{6999} & \multirow{3}{*}{301} & \multirow{3}{*}{10.73} \\
\hline & Chinese Journal of Law (10) & & & \\
\hline & Peking University Law Journal (10) & & & \\
\hline
\end{tabular}

\section{B. Framework of the Analysis}

The framework of the present study draws on Swales' CARS model (1990) and Hyland's five-move model (2000) as presented in table 2. Even though Swales' CARS model was initially used to analyze introductions of RAs, it was proved to be efficient in studying abstracts as both parts bore certain similar communicative purposes. A top-down approach is adopted to analyze the selected abstracts. Ten abstracts (five English and five Chinese) are first examined carefully by the author to decide on the communicative purposes of different information segments and to see how well they correspond to the moves of the aforementioned two models, based on which a preliminary mover structure model for the present study is constructed. Then the rest of the abstracts are investigated according to the preliminary model and adjustments are made in due course. Finally, the adjusted model is used to analyze all the abstracts in the corpus once again to see if any further changes are needed. The analysis is done with the help of a specialist informant majoring in law. The adjusted move structure model is presented in table 3.

TABLE 2

JOHN SWALES' CARS MODEL AND HYLAND’S FIVE-MOVE MODEL

\begin{tabular}{|c|c|}
\hline John Swales' CARS Model (1990) & Hyland's five-move Model (2000) \\
\hline Move 1 Establishing a territory & Move 1- Introduction \\
\hline $\begin{array}{c}\text { Step } 1 \text { Claiming centrality } \\
\text { and/or }\end{array}$ & $\begin{array}{l}\text { Establishes context of the paper and motivates the research or } \\
\text { discussion. }\end{array}$ \\
\hline Step 2 Making topic generalization(s) & \\
\hline and/or & Move 2-Purpose \\
\hline Step 3 Reviewing items of previous research & Indicates purpose, thesis or hypothesis, outline the intention \\
\hline $\begin{array}{l}\text { Move } 2 \text { Establishing a niche } \\
\text { Step 1A Counter-claiming }\end{array}$ & behind the paper. \\
\hline or & Move 3-Method \\
\hline $\begin{array}{c}\text { Step 1B Indicating a gap } \\
\text { or }\end{array}$ & $\begin{array}{l}\text { Provides information on design, procedures, assumptions, } \\
\text { approach, data, etc. }\end{array}$ \\
\hline Step 1C Question-raising & \\
\hline & Move 4 -Product \\
\hline $\begin{array}{l}\text { Step 1D Continuing a tradition } \\
\text { Move } 3 \text { Occupving the niche }\end{array}$ & States main findings or results, the argument, or what was \\
\hline Step 1A Outlining purposes & 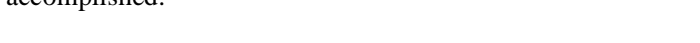 \\
\hline or & Move 5-Conclusion \\
\hline Step 1B Announcing present research & Interprets or extends results beyond scope of paper, draws \\
\hline Step 2 Announcing principal findings & inferences, points to applications or wider implications. \\
\hline Step 3 Indicating RA structure & \\
\hline
\end{tabular}

TABLE 3

The Adjusted Move Structure Model

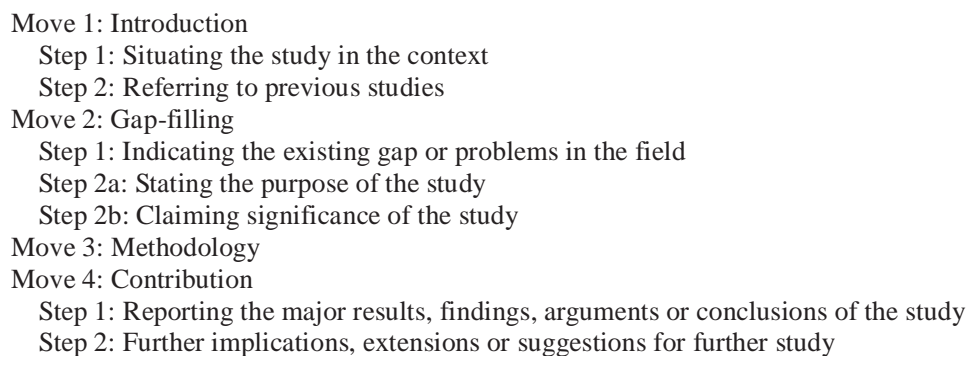

This model puts emphasis on the communicative purposes of "summarizing" and "marketing" of abstracts. Introduction move serves as the lead-in part to provide background information of the present study as to "what is the status quo" of the field, showing the author's academic knowledge and situate the study in the academic discourse 
community. Gap-filling move puts forward the existing problems or gaps in the field in order to justify the study and persuade the readers that the present paper deserves attention, which further enhances the author's credibility and arouses readers' interest. This move concerns "what can be changed, added and developed" in the field. Methodology move introduces the methods adopted to do the research. Contribution move reports major results or findings of the study, providing a more complete picture of the following paper. Further implications and suggestions extend the results and highlight the contribution of the present study, relating it to other members of the discourse community and further promoting the paper. This move deals with "what has been achieved and its contribution" in the field.

It is reasonable to believe that an abstract does not necessarily include all of the moves based on the writing traditions, requirements and practices in different fields. Some moves occur more frequently while others do not. Researchers hold different views as regards move stability, that is, a move that occurs regularly in a genre will be considered conventional and thus obligatory. Swales (1990) believes that if a move appears in no less than $50 \%$ of the investigated instances, that move is obligatory; moves with a lower frequency are considered optional. Other opinions concerning move stability are 60\% (Kanoksilapatham, 2005), 66\% (Hatzitheodorou, 2014), 90\% (Santos, 1996), and 100\% (Cross \& Oppenheim, 2006; Tseng, 2011).

Therefore, the frequency of each move in the selected corpus is calculated and summed based on the presented model in an attempt to investigate how the RA abstracts in the field of law reach their communicative purposes.

\section{RESULTS AND DISCUSSION}

\section{A. Moves and Their Frequencies}

In an attempt to answer the first two research questions, the corpus of 60 legal RA abstracts in both English and Chinese were analyzed carefully in terms of move patterns based on the proposed model. Table 4 lists the number of abstracts featuring each move in the corpus; and table 5 shows the number of abstracts featuring each step in the corpus.

TABLE 4

THE Number Of ABstracts FeATuring THE MOVE IN ENGLish AND CHINESE Corpus

\begin{tabular}{lcccc}
\hline \multirow{2}{*}{ Moves } & \multicolumn{3}{c}{ English } & \multicolumn{2}{c}{ Chinese } \\
\cline { 2 - 5 } & Number & Percentage & 22 & Percentage \\
\hline M1: Introduction & 27 & $90.00 \%$ & 23 & $73.33 \%$ \\
M2: Gap-filling & 27 & $90.00 \%$ & 5 & $76.67 \%$ \\
M3: Methodology & 11 & $36.67 \%$ & 29 & $16.67 \%$ \\
M4: Contribution & 30 & $100 \%$ & $96.67 \%$ \\
\hline
\end{tabular}

TABLE 5

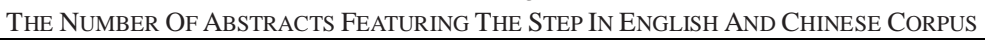

\begin{tabular}{|c|c|c|c|c|}
\hline \multirow{2}{*}{ Moves \& Steps } & \multicolumn{2}{|c|}{ English } & \multicolumn{2}{|c|}{ Chinese } \\
\hline & Number & Percentage & Number & $\begin{array}{l}\text { Percentag } \\
\text { e }\end{array}$ \\
\hline \multicolumn{5}{|l|}{ M1:Introduction } \\
\hline S1:Situating the study & 25 & $83.33 \%$ & 22 & $73.33 \%$ \\
\hline S2:Referring to previous studies & 10 & $33.33 \%$ & 0 & $0.00 \%$ \\
\hline \multicolumn{5}{|l|}{ M2:Gap-filling } \\
\hline S1:Indicating the gap & 16 & $53.33 \%$ & 20 & $66.67 \%$ \\
\hline S2a:Stating the purpose & 22 & $73.33 \%$ & 7 & $23.33 \%$ \\
\hline S2b:Claiming significance & 8 & $26.67 \%$ & 4 & $13.33 \%$ \\
\hline M3:Methodology & 11 & $36.67 \%$ & 5 & $16.67 \%$ \\
\hline \multicolumn{5}{|l|}{ M4: Contribution } \\
\hline S1:Reporting major results & 30 & $100 \%$ & 29 & $96.67 \%$ \\
\hline S2:Further extensions & 18 & $60 \%$ & 11 & $36.67 \%$ \\
\hline
\end{tabular}

As is shown in the table, three frequent moves are identified in both English and Chinese legal RA abstracts-Introduction, Gap-filling and Contribution, with differences in the percentage. If the threshold of move stability is set too high, then some variations may not be identified, especially in the fields of humanities where research topics are not so well-defined as in social sciences. Therefore, the present study opts to follow Hatzitheodorou's view (2014) to decide the move stability. Introduction and Gap-filling occur in 27 of the selected English abstracts, consisting $90 \%$ and Contribution occur in all of them, consisting 100\%. Those numbers are less in Chinese corpus but still take more than seventy percent of the total. Methodology move takes the smallest portion in both languages but its frequency in Chinese is less than half of that in English. Thus it is safe to say that the moves of Introduction, Gap-filling and Contribution are stable or obligatory while Methodology optional in the corpus. Taking a closer look at the frequency of each step, bigger differences are found between the English and Chinese legal RA abstracts. In English, the most frequent moves are M4S1/results (100\%), M1S1/introduction (83.33\%) and M2S2a/purpose (73.33\%) whereas in Chinese, the most frequent moves are M4S1/results (96.67\%), M1S1/introduction (73.33\%) and M2S1/gap (66.67\%).

\section{B. Functions and Features of Each Move}

\section{Move 1: Introduction}


This move, usually placed at the beginning of abstracts, introduces the background and research topic of the RA while preparing readers for what comes next. It consists of two steps: step1-situating the study in the context and step 2- referring to previous studies. Different from hard sciences, soft sciences such as legal research usually work much harder to acquaint readers with the background to their research and to construct its significance rhetorically because community members participate in less clearly identifiable areas of study and proceed along less heavily trodden paths of research (Hyland, 2000). As legal RAs in this corpus cover a wide range of branches and issues including constitutional law, economic law, administrative law, etc., researchers of one area may not be familiar with another, as a result, M1 is frequently employed to contextualize the study and familiarize readers with the topic. The high percentage of M1 in both English and Chinese corpus attests to the statement that Introduction providing a general context were more common in in the humanities and social sciences because they tend to be more diverse and have more permeable boundaries (Hyland, 2000).

As is seen in table 5, one thing worth noting is that although M1S1 in both English and Chinese exhibit frequent occurrences $(83.33 \%$ and $73.33 \%$ respectively), M1S2 in Chinese corpus exhibit none while in English it is found in one third of the abstracts $(33.33 \%)$. The reason may be that Chinese writers try to make their abstracts precise and concise due to the limit of space and thus focus on their own studies, saving "previous studies" to the introduction and literature review part of the paper. This interesting difference reflects different academic writing practices in the field of law in English and Chinese. For example:

1) The concept of "information fiduciaries" has surged to the forefront of debates on online-platform regulation.(M1S1) Developed by Professor Jack Balkin, the concept is meant to rebalance the relationship...Balkin argues...(M1S2)

2) 《反不正当竞争法》引入的网络条款旨在评价网络竞争行为的正当性。(M1S1) (translation: The Internet-related provisions introduced by the Law against Unfair Competition are aimed at evaluating the legitimacy of online competition.)

2. Move 2: Gap-filling

This move consists of two steps: Step 1-Indicating the gap, and Step 2-Stating the purpose or Claiming significance of the present study. Step 1 expressly points out the lack of knowledge or the problems in the research field. Step 2 fulfills the Gap presented by demonstrating the purpose of the study or explaining how important the study is. Gap-filling move shares some common functions with M2 (Establishing a niche) in Swales' CARS model, but with a more direct goal to "sell" or "market" the paper. Though the two steps of Move 2, the author is able to, first, boost his credibility and professionalism as an insider in the field by putting forward the "Gap" that other members of the community may have not noticed, thus attracting readers and provoking their thinking; second, to encourage further reading into the article to learn more about the problem or solution by stressing purpose and significance of the study. As is shown in the table, M2 has the second most frequent occurrences in the abstracts of both languages (in English M1 and M2 have the same percentage), however, the distribution of S1 and S2 is different. In English, Stating the purpose is the most common one with a percentage of $73.33 \%$ while in Chinese it is much less-only $23.33 \%$. Indicating the gap, on the other hand, has the percentage of $66.67 \%$ in Chinese while in English this number is $52.33 \%$. Claiming significance has a low frequency rate in both languages, with English $26.67 \%$ and Chinese half of it. This shows that English authors tend to encourage readership by stating clearly the purpose and goals of the study while Chinese authors seem to do it by pointing out the lack of knowledge or the problems in the research field. For example:

3) ... But while it might appear that any internet user can publish freely and instantly online, many platforms actively curate the content posted by their users. How and why these platforms operate to moderate speech is largely opaque (M2S1). This Article provides the first analysis of what these platforms are actually doing to moderate online speech under a regulatory and First Amendment framework (M2S2aS2b)...

4) …然而, 10 年实践表明:由于责任分配不清、科层压力不够, 行政保障面临制度配套不足、考评追责乏力和 监督救济缺失的困境(M2S1); 法院则突破限制, 探索多样化的审查方式, 对公共企事业单位的信息公开活动积极 开展监督 $(\mathrm{M} 2 \mathrm{~S} 2 \mathrm{a}) \ldots$ (translation: ...However, Ten years of practice show that due to unclear distribution of responsibilities and insufficient pressure from different levels, administrative security is faced with the difficulties of inadequate system support, weak evaluation and accountability and lack of supervision and relief; the court, on the other hand, broke through the restrictions, explored various ways of examination, and actively carried out supervision over the information disclosure activities of public enterprises and institutions... )

One thing needs to be mentioned here is that sometimes one step may be embedded in another. As in example 3, right after indicating the "Gap", the author directly and logically states the purpose of the study responding to the "Gap". By using "the first analysis", the author "promotes" or "sells" the study as "the first" in the research area, which demonstrates the significance of the study and further intrigued the readers.

3. Move 3: Methodology

Methodology move describes the materials, subjects, procedures and other elements involved in the way the study is conducted. It is obvious, as is shown in table 5, that the move of Methodology is optional in both English and Chinese legal RA abstracts, with the frequency of $36.67 \%$ in English corpus and $16.67 \%$ in Chinese, much less than that of other moves. This somehow attests to Hyland's opinion (2000) that writers in the soft knowledge domains saw a greater need to situate their discourse with an Introduction while those in hard disciplines showed a preference for a description of 
the Method. Moreover, it is found that the Methodology move in the corpus is usually concise without taking up too much space in the abstracts and some are embedded in other moves, which further indicates that scholars in the field of law pay less attention to the description of methodology in writing abstracts. For example:

5) ...Through an original behavioral study (M3), this Note reveals flaws in the fundamental assumptions of both camps...(M3 embedded in M4)

6) ....从语义、语境、渊源等多方面解构“合理”一词(M3), 可得出“合理”在法学领域应用中的四种意涵... (M3 embedded in M4)

(translation:...Deconstructing the word "reasonable" from multi-dimensions of semantics, context, origin and other aspects, we can derive four meanings of it in the application of law...)

4. Move 4: Contribution

This move foregrounds the Contribution of the study to the field, serving the communicative purposes of "summarizing results" and "further marketing the study". It consists of two steps: Step 1-reporting major findings, results or argument and step 2-providing further extensions or implications. In most cases, it is the last move in the abstracts and emphasizes the contribution of the study in order to encourage readers to finish reading the whole paper that follows rather than skip to the next one. Therefore, this move occurs most frequently in the corpus studied, with $100 \%$ in the English abstracts and $96.67 \%$ in the Chinese ones. It is worth mentioning that as long as M4 occurs, there must be M4S1 but not necessarily M4S2. On the one hand, the high frequency of M4S1 implies that it is almost a must in both English and Chinese to report the results, major findings or arguments of the study in constructing legal RA abstracts; on the other hand, the frequency of M4S2 is 60\% in English and 36.67\% in Chinese, indicating that it is more common to provide readers with further extensions and implications of the study in English legal RA abstracts than Chinese. This result is in line with Hyland's study (2000) where he found 94\% of the data included a Product (Product move in Hyland's model resembles M4S1 in the proposed model in this study) statement that presented the main argument or findings. Writers are anxious to underline their most central claims as a means of gaining reader interest and acceptance, underlying the assertion by Berkenkotter and Huckin (1995) that the abstract is essentially a promotional genre. For instance:

7) ...The empirical analysis reveals that agencies have been increasingly engaging in regulatory bundling for the last two decades. More generally, bundling behavior varies widely across different administrative agencies, and agencies appear to include more subjects in their final-as opposed to proposed-rules. (M4S1) These findings, in turn, raise significant normative concerns that could be addressed through a suite of tools novel to the administrative state: single subject rules, line-item vetoes, and innovative uses of more traditional doctrines of judicial review. Whether some of these tools should be adopted, however, requires further empirical assessment of regulatory bundling's causes and consequences. (M4S2)

8) ...因此，市场与政府不只是补充关系，更有互为支撑、相互转化的交叉关系。(M4S1)循此逻辑，方能建立 张弛有度、与时俱进、尽如所期的社会主义市场经济法律体系。(M4S2)

(translation:...Therefore, the market and the government are not only complementary, but also interdependent. They support and transform each other. Only by following this logic can we establish a flexible and current legal system of socialist market economy that fulfills its expectations.)

The results of this study are slightly different from Hatzitheodorou's findings (2014) when she compared the move structures of abstracts in law journals and business journals. The moves that appear most often were 2a/Gap, 2b/Goal and 3a/Discussion of results (80\% for all three) in her corpus of legal RA abstracts. But in the present study, the most frequent moves are M4S1/Results (100\%), M1S1/Introduction (83.33\%) and M2S2a/Purpose (73.33\%). More interestingly, in Ghasempour and Farnia's cross-linguistic study (2017), their results of English legal RA abstracts showed that Purpose $(91.11 \%)$, Method $(80.00 \%)$ and Conclusion $(71.11 \%)$ were most frequent moves. The frequency of Method is a far cry from other studies including the present one. Maybe it is because the writing practices and requirements of different journals vary in the field of law or scholars engaging in different laws abide by different writing norms.

\section{Move Structures}

In order to further understand the move structures of the corpus, each abstract is analyzed, marked and described with move sequences; then those move sequences are collected and arranged by the computer. The results are listed as follows: 

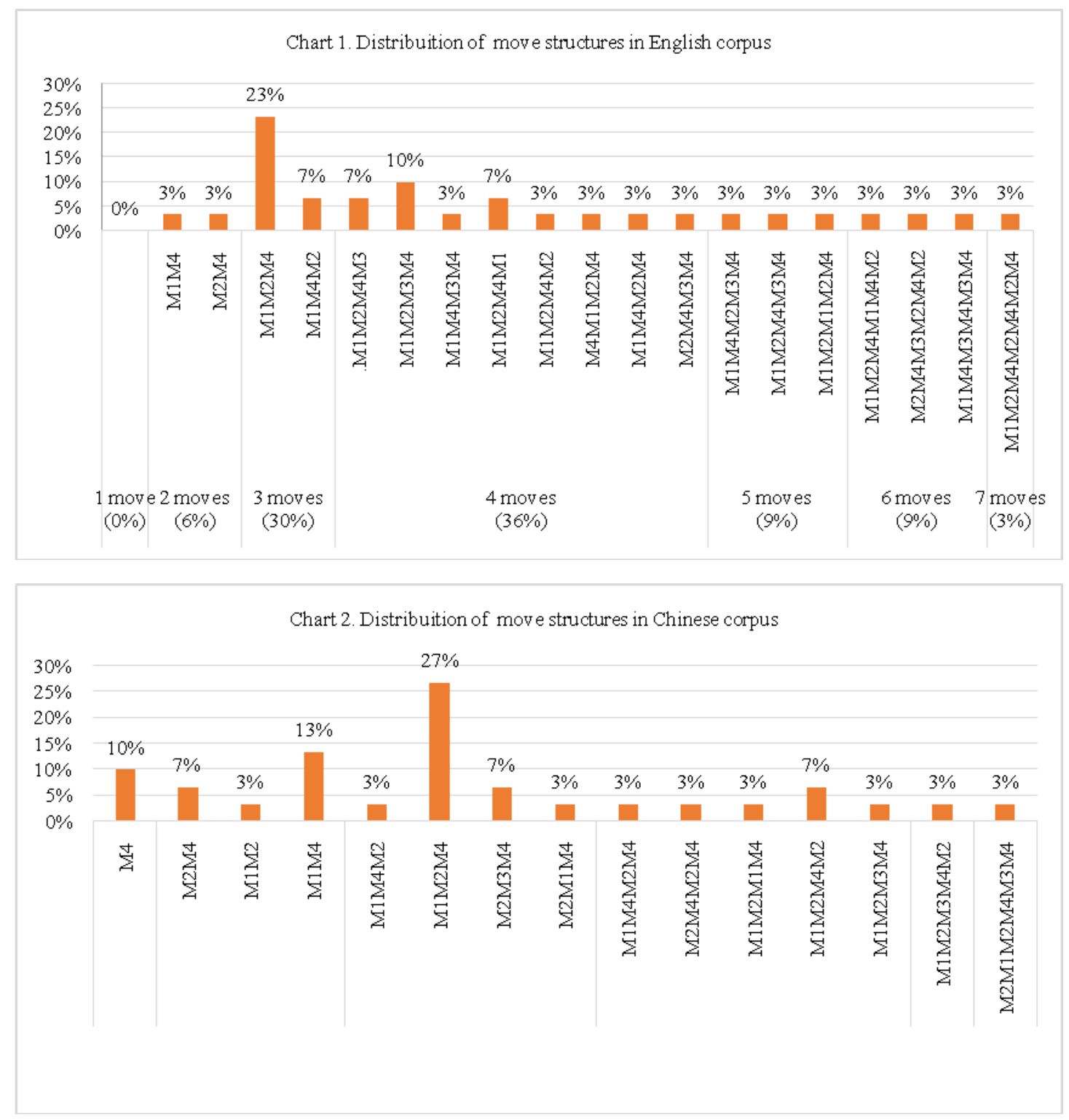

Several points can be made clear according to the above two charts: first, $23 \%$ of abstracts in English contain all of the four moves as proposed in the model (recurring structures included) but it is only $9 \%$ in Chinese abstracts. Thus the move structures of abstracts in English corpus, with more recurring move cycles in one abstract, are obviously more complicated than those in Chinese. Second, the most dominant in English corpus is the four-move structure, accounting for $36 \%$ of all cases while in Chinese corpus that is the three-move structure, comprising $40 \%$ of all cases. Third, the most frequent move structures in English corpus are the sequences M1-M2-M4 (23\%) and M1-M2-M3-M4 (10\%), and in Chinese corpus those are M1-M2-M4 (27\%) and M1-M4 (13\%). The dominance of the move structure M1-M2-M4 in both languages (though with different percentages) in this study share some common ground with Hyland's claim (2000) that humanities/social science writers shows a general preference for the I-P-Pr model whereas physicists and engineers tend to opt for the P-M-Pr pattern. Fourth, 84\% of the abstracts in English corpus start with M1 and 65\% in Chinese corpus start with it; the rest of the abstracts start with either M2 or M4 and no abstracts start with M3. This indicates that English writers feel more obliged to situate their discourse with an Introduction and writers of both languages may not regard the description of methodology as helpful or efficient in promoting their study. The last point worth noting is that one-move pattern is found in three Chinese abstracts, all of which consist of M4 (to be specific, M4S1S2), but no one-move pattern is found in English abstracts. However, move structures with more than four moves in English corpus take up about $21 \%$ while that number in Chinese is only $6 \%$. This further shows that the abstracts in English tend to display more complicated and recurring move structures.

\section{CONCLUSION}

This study contributes to the expanding research of genre study and EAP and fills the research gap as the study on English and Chinese legal RA abstracts has been quite rare so far. By analyzing the moves of legal RA abstracts in both 
English and Chinese, this study proposed a move model based on which the comparative study is conducted. The findings show that apart from move 3 (Methodology), other moves are obligatory in both English and Chinese legal RA abstracts. Furthermore, while both English and Chinese legal RA abstracts attach great importance to reporting the major results of the study (M4S1) and projecting a specific disciplinary context in order to situate the study within it (M1S1), English abstracts tend to state explicitly the purposes (M2S2a) and Chinese abstracts show a preference for pointing out the "Gap" first. In addition, it is found that English legal RA abstracts are generally more complicated in move structures than Chinese ones, as the dominant move structure in English is four-move sequence and that in Chinese is three-move sequence.

This study provides important inspirations for scholars in the field of law, both English and Chinese, to help them understand better the generally writing practices in the two professional discourse communities thus promoting communication and exchanges. It also has pedagogical implications for teachers and students in ESP and EAP fields. English academic writing can be more explicitly and creatively taught to students who seek to engage in the international academic circle and vice versa. On the one hand, better awareness of RA abstracts as a "promotional" or "marketing" genre guide writers in producing effective academic discourses that follow certain norms with more smooth move signaling and research space creation, which is likely to increase their chances for publication and draw more attention from the academic discourse communities; on the other hand, familiarity with genre practices in the certain field facilitate readers' understanding of RA abstracts and boost efficiency of reading.

There are also some limitations with respect to the present study. As the corpus comprises of only 60 abstracts altogether and are selected from six rather prestigious journals, the results may illustrate the best disciplinary writing practices in both English and Chinese discourse communities. A larger corpus from a wider selection of journals will provide a bigger picture for scholars both in genres and law. The findings of the study can also be taken a step further with interviews of legal scholars and other professional background research to explore the rationale behind those similarities and differences. Moreover, the exploration of other linguistic features of each move such as voice, tense, self-mentions and syntactic complexity is expected to expand the study.

\section{APPENDIXES}

1. Moves in the selected research article abstracts (those in the brackets represent embedded moves):

\begin{tabular}{|c|c|c|}
\hline No. & English abstracts & Chinese abstracts \\
\hline 1 & $\mathrm{M}_{1} \mathrm{~S}_{1} \mathrm{M}_{2} \mathrm{~S}_{1} \mathrm{~S}_{2 \mathrm{a}}\left(\mathrm{S}_{2 \mathrm{~b}}\right) \mathrm{M}_{4} \mathrm{~S}_{1}\left(\mathrm{M}_{3}\right) \mathrm{S}_{2}$ & $\mathrm{M}_{1} \mathrm{~S}_{1} \mathrm{M}_{4} \mathrm{~S}_{1}\left(\mathrm{M}_{2} \mathrm{~S}_{1}\right) \mathrm{S}_{2}$ \\
\hline 2 & $\mathrm{M}_{1} \mathrm{~S}_{2} \mathrm{M}_{2} \mathrm{~S}_{1} \mathrm{~S}_{2 \mathrm{a}} \mathrm{M}_{4} \mathrm{~S}_{1}$ & $\mathrm{M}_{2} \mathrm{~S}_{1} \mathrm{M}_{4} \mathrm{~S}_{1}$ \\
\hline 3 & $\mathrm{M}_{1} \mathrm{~S}_{1} \mathrm{M}_{2} \mathrm{~S}_{1} \mathrm{M}_{4} \mathrm{~S}_{1} \mathrm{M}_{1} \mathrm{~S}_{2} \mathrm{M}_{4} \mathrm{~S}_{2} \mathrm{M}_{2} \mathrm{~S}_{2 \mathrm{a}}$ & $\mathrm{M}_{1} \mathrm{~S}_{1} \mathrm{M}_{2} \mathrm{~S}_{1} \mathrm{~S}_{2 \mathrm{~b}}$ \\
\hline 4 & $\mathrm{M}_{1} \mathrm{~S}_{1} \mathrm{~S}_{2} \mathrm{M}_{2} \mathrm{~S}_{2 \mathrm{a}}\left(\mathrm{M}_{3}\right) \mathrm{M}_{4} \mathrm{~S}_{1}$ & $\mathrm{M}_{1} \mathrm{~S}_{1} \mathrm{M}_{4} \mathrm{~S}_{1} \mathrm{~S}_{2}$ \\
\hline 5 & $\mathrm{M}_{1} \mathrm{~S}_{2} \mathrm{~S}_{1} \mathrm{M}_{4} \mathrm{~S}_{1}\left(\mathrm{M}_{2} \mathrm{~S}_{2 \mathrm{a}}\right) \mathrm{M}_{3} \mathrm{M}_{4} \mathrm{~S}_{2}$ & $\mathrm{M}_{1} \mathrm{~S}_{1} \mathrm{M}_{2} \mathrm{~S}_{1} \mathrm{M}_{4} \mathrm{~S}_{1}$ \\
\hline 6 & $\mathrm{M}_{1} \mathrm{~S}_{1} \mathrm{M}_{4} \mathrm{~S}_{1} \mathrm{M}_{3} \mathrm{M}_{4} \mathrm{~S}_{1} \mathrm{~S}_{2}$ & $\mathrm{M}_{1} \mathrm{~S}_{1} \mathrm{M}_{2} \mathrm{~S}_{1} \mathrm{~S}_{2 \mathrm{a}} \mathrm{M}_{4} \mathrm{~S}_{1}$ \\
\hline 7 & $\mathrm{M}_{1} \mathrm{~S}_{1} \mathrm{M}_{2} \mathrm{~S}_{1} \mathrm{MS}_{2 \mathrm{a}}\left(\mathrm{S}_{2 \mathrm{~b}}\right) \mathrm{M}_{3} \mathrm{~S}_{1}$ & $\mathrm{M}_{1} \mathrm{~S}_{1} \mathrm{M}_{2} \mathrm{M}_{1} \mathrm{M}_{4} \mathrm{~S}_{1}$ \\
\hline 8 & $\mathrm{M}_{1} \mathrm{~S}_{2} \mathrm{M}_{2} \mathrm{~S}_{1} \mathrm{~S}_{2 \mathrm{a}}\left(\mathrm{S}_{2 \mathrm{~b}}\right) \mathrm{M}_{4} \mathrm{~S}_{1} \mathrm{~S}_{2}$ & $\mathrm{M}_{1} \mathrm{~S}_{1} \mathrm{M}_{2} \mathrm{~S}_{1} \mathrm{M}_{4} \mathrm{~S}_{1}$ \\
\hline 9 & $\mathrm{M}_{1} \mathrm{~S}_{1} \mathrm{M}_{2} \mathrm{~S}_{2 \mathrm{a}} \mathrm{M}_{4} \mathrm{~S}_{1}\left(\mathrm{M}_{1} \mathrm{~S}_{2}\right)$ & $\mathrm{M}_{1} \mathrm{~S}_{1} \mathrm{M}_{2} \mathrm{~S}_{2 \mathrm{~b}} \mathrm{M}_{3} \mathrm{M}_{4} \mathrm{~S}_{1} \mathrm{M}_{2} \mathrm{~S}_{2 \mathrm{a}}$ \\
\hline 10 & $\mathrm{M}_{1} \mathrm{~S}_{1} \mathrm{M}_{2} \mathrm{~S}_{1} \mathrm{M}_{4} \mathrm{~S}_{1}$ & $\mathrm{M}_{2} \mathrm{~S}_{1} \mathrm{M}_{3} \mathrm{M}_{4} \mathrm{~S}_{1}$ \\
\hline 11 & $\mathrm{M}_{1} \mathrm{~S}_{1} \mathrm{M}_{4} \mathrm{~S}_{1} \mathrm{~S}_{2}$ & $\mathrm{M}_{2} \mathrm{~S}_{2 \mathrm{~b}} \mathrm{M}_{1} \mathrm{~S}_{1} \mathrm{M}_{4} \mathrm{~S}_{1}$ \\
\hline 12 & $\mathrm{M}_{1} \mathrm{~S}_{1} \mathrm{M}_{4} \mathrm{~S}_{1}\left(\mathrm{M}_{2} \mathrm{~S}_{2 \mathrm{a}}\right) \mathrm{S}_{2}$ & $\mathrm{M}_{1} \mathrm{~S}_{1} \mathrm{M}_{2} \mathrm{~S}_{1} \mathrm{M}_{4} \mathrm{~S}_{1} \mathrm{~S}_{2}$ \\
\hline 13 & $\mathrm{M}_{1} \mathrm{~S}_{1} \mathrm{~S}_{2} \mathrm{M}_{2} \mathrm{~S}_{2 \mathrm{a}} \mathrm{M}_{4} \mathrm{~S}_{1}\left(\mathrm{M}_{2} \mathrm{~S}_{1}\right)$ & $\mathrm{M}_{1} \mathrm{~S}_{1} \mathrm{M}_{2} \mathrm{~S}_{1} \mathrm{~S}_{2 \mathrm{a}}(\mathrm{embedded}) \mathrm{M}_{4} \mathrm{~S}_{1}$ \\
\hline 14 & $\mathrm{M}_{1} \mathrm{~S}_{1} \mathrm{M}_{2} \mathrm{~S}_{1} \mathrm{M}_{4} \mathrm{~S}_{1} \mathrm{~S}_{2}$ & $\mathrm{M}_{2} \mathrm{~S}_{1} \mathrm{M}_{4} \mathrm{~S}_{1} \mathrm{M}_{2} \mathrm{~S}_{1} \mathrm{M}_{4} \mathrm{~S}_{1}$ \\
\hline 15 & $\mathrm{M}_{2} \mathrm{~S}_{2 \mathrm{a}} \mathrm{S}_{2} \mathrm{bM}_{4} \mathrm{~S}_{1}$ & $\mathrm{M}_{2} \mathrm{~S}_{1} \mathrm{M}_{4} \mathrm{~S}_{1}$ \\
\hline 16 & $\mathrm{M}_{2} \mathrm{~S}_{1} \mathrm{M}_{4} \mathrm{~S}_{1}\left(\mathrm{M}_{3}\right) \mathrm{M}_{2} \mathrm{~S}_{1} \mathrm{M}_{4} \mathrm{~S}_{1}\left(\mathrm{M}_{2} \mathrm{~S}_{1} \mathrm{~S}_{2 \mathrm{a}}\right) \mathrm{S}_{2}$ & $\mathrm{M}_{1} \mathrm{~S}_{1} \mathrm{M}_{2} \mathrm{~S}_{2 \mathrm{a}} \mathrm{M}_{1} \mathrm{~S}_{1} \mathrm{M}_{4} \mathrm{~S}_{1} \mathrm{~S}_{2}$ \\
\hline 17 & $\mathrm{M}_{4} \mathrm{~S}_{1} \mathrm{M}_{1} \mathrm{~S}_{2} \mathrm{M}_{2} \mathrm{~S}_{2} \mathrm{bM}_{4} \mathrm{~S}_{1} \mathrm{~S}_{2}$ & $\mathrm{M}_{4} \mathrm{~S}_{1} \mathrm{~S}_{2}$ \\
\hline 18 & $\mathrm{M}_{1} \mathrm{~S}_{1} \mathrm{M}_{4} \mathrm{~S}_{1}\left(\mathrm{M}_{3}\right) \mathrm{M}_{3} \mathrm{M}_{4} \mathrm{~S}_{1} \mathrm{~S}_{2}$ & $\mathrm{M}_{1} \mathrm{~S}_{1} \mathrm{M}_{2} \mathrm{~S}_{1} \mathrm{M}_{4} \mathrm{~S}_{1}\left(\mathrm{M}_{2} \mathrm{~S}_{2 \mathrm{a}}\right)$ \\
\hline 19 & $\mathrm{M}_{1} \mathrm{~S}_{1} \mathrm{M}_{2} \mathrm{~S}_{2 \mathrm{~b}} \mathrm{M}_{4} \mathrm{~S}_{1} \mathrm{M}_{3} \mathrm{M}_{4} \mathrm{~S}_{1} \mathrm{~S}_{2}$ & $\mathrm{M}_{1} \mathrm{~S}_{1} \mathrm{~S}_{2 \mathrm{a}}\left(\mathrm{M}_{3}\right) \mathrm{M}_{4} \mathrm{~S}_{1} \mathrm{~S}_{2}$ \\
\hline 20 & $\mathrm{M}_{1} \mathrm{~S}_{2} \mathrm{M}_{2} \mathrm{~S}_{1} \mathrm{~S}_{2 \mathrm{a}} \mathrm{M}_{4} \mathrm{~S}_{1}$ & $\mathrm{M}_{4} \mathrm{~S}_{1} \mathrm{~S}_{2}$ \\
\hline 21 & $\mathrm{M}_{1} \mathrm{~S}_{1} \mathrm{M}_{2} \mathrm{~S}_{2 \mathrm{a}} \mathrm{S}_{1} \mathrm{~S}_{2 \mathrm{a}} \mathrm{M}_{4} \mathrm{~S}_{1} \mathrm{M}_{2} \mathrm{~S}_{2 \mathrm{a}} \mathrm{M}_{4} \mathrm{~S}_{1} \mathrm{M}_{2} \mathrm{~S}_{2 \mathrm{a}} \mathrm{M}_{4} \mathrm{~S}_{1}$ & $\mathrm{M}_{1} \mathrm{~S}_{1} \mathrm{M}_{2} \mathrm{~S}_{1} \mathrm{M}_{4} \mathrm{~S}_{1}$ \\
\hline 22 & $\mathrm{M}_{2} \mathrm{~S}_{2 \mathrm{a}}\left(\mathrm{S}_{2 \mathrm{~b}}\right) \mathrm{M}_{4} \mathrm{~S}_{1} \mathrm{M}_{3} \mathrm{M}_{4} \mathrm{~S}_{1} \mathrm{~S}_{2}$ & $\mathrm{M}_{1} \mathrm{~S}_{1} \mathrm{M}_{4} \mathrm{~S}_{1} \mathrm{~S}_{2}$ \\
\hline 23 & $\mathrm{M}_{1} \mathrm{~S}_{1} \mathrm{M}_{2} \mathrm{~S}_{1} \mathrm{M}_{3} \mathrm{M}_{4} \mathrm{~S}_{1}$ & $\mathrm{M}_{2} \mathrm{~S}_{1} \mathrm{M}_{1} \mathrm{~S}_{1} \mathrm{M}_{2} \mathrm{~S}_{1} \mathrm{M}_{4} \mathrm{~S}_{1} \mathrm{M}_{3} \mathrm{M}_{4} \mathrm{~S}_{1}$ \\
\hline 24 & $\mathrm{M}_{1} \mathrm{~S}_{1} \mathrm{M}_{2} \mathrm{~S}_{1} \mathrm{~S}_{2 \mathrm{a}} \mathrm{M}_{1} \mathrm{~S}_{2} \mathrm{M}_{2} \mathrm{~S}_{1} \mathrm{M}_{4} \mathrm{~S}_{1} \mathrm{~S}_{2}$ & $\mathrm{M}_{1} \mathrm{~S}_{1} \mathrm{M}_{2} \mathrm{~S}_{1} \mathrm{M}_{4} \mathrm{~S}_{1}$ \\
\hline 25 & $\mathrm{M}_{1} \mathrm{~S}_{1} \mathrm{M}_{2} \mathrm{~S}_{2 \mathrm{~b}} \mathrm{~S}_{2 \mathrm{a}} \mathrm{M}_{4} \mathrm{~S}_{1}\left(\mathrm{M}_{3}\right) \mathrm{S}_{2}$ & $\mathrm{M}_{1} \mathrm{~S}_{1} \mathrm{M}_{2} \mathrm{~S}_{1} \mathrm{M}_{4} \mathrm{~S}_{1}$ \\
\hline 26 & $\mathrm{M}_{1} \mathrm{~S}_{1} \mathrm{M}_{4} \mathrm{~S}_{1} \mathrm{M}_{2} \mathrm{~S}_{1} \mathrm{~S}_{2 \mathrm{a}}$ & $\mathrm{M}_{4} \mathrm{~S}_{1} \mathrm{~S}_{2}$ \\
\hline 27 & $\mathrm{M}_{1} \mathrm{~S}_{1} \mathrm{~S}_{2} \mathrm{M}_{2} \mathrm{~S}_{1} \mathrm{~S}_{2 \mathrm{a}} \mathrm{M}_{3} \mathrm{M}_{4} \mathrm{~S}_{1} \mathrm{~S}_{2}$ & $\mathrm{M}_{1} \mathrm{~S}_{1} \mathrm{M}_{2} \mathrm{~S}_{2 \mathrm{a}} \mathrm{M}_{3} \mathrm{M}_{4} \mathrm{~S}_{1}$ \\
\hline 28 & $\mathrm{M}_{1} \mathrm{~S}_{1} \mathrm{M}_{2} \mathrm{~S}_{2 \mathrm{a}} \mathrm{M}_{4} \mathrm{~S}_{1} \mathrm{~S}_{2}$ & $\mathrm{M}_{1} \mathrm{~S}_{1} \mathrm{M}_{4} \mathrm{~S}_{1}$ \\
\hline 29 & $\mathrm{M}_{1} \mathrm{~S}_{1} \mathrm{M}_{4} \mathrm{SM}_{2} \mathrm{~S}_{1} \mathrm{~S}_{2 \mathrm{a}} \mathrm{M}_{4} \mathrm{~S}_{1}$ & $\mathrm{M}_{1} \mathrm{~S}_{1} \mathrm{M}_{2} \mathrm{~S}_{1} \mathrm{M}_{4} \mathrm{M}_{1} \mathrm{M}_{2} \mathrm{~S}_{2 \mathrm{~b}}$ \\
\hline 30 & $\mathrm{M}_{1} \mathrm{~S}_{1} \mathrm{M}_{2} \mathrm{~S}_{2 \mathrm{a}} \mathrm{M}_{4} \mathrm{~S}_{1}\left(\mathrm{M}_{1} \mathrm{~S}_{2}\right) \mathrm{S}_{2}$ & $\mathrm{M}_{1} \mathrm{~S}_{1} \mathrm{M}_{2} \mathrm{~S}_{1} \mathrm{M}_{4} \mathrm{~S}_{1}$ \\
\hline
\end{tabular}




\section{The move structure model before and after the revision:}

\begin{tabular}{|l|l|}
\hline Before revision & After revision \\
\hline Move 1: Background & Move 1: Introduction \\
Step 1: Situating the study in the context & Step 1: Situating the study in the context \\
Step 2: Referring to previous studies & Step 2: Referring to previous studies \\
Step 3: Claiming significance of the study & Move 2: Gap-filling \\
Move 2: Gap-filling & Step 1: Indicating the existing gap or problems in the field \\
Step 1: Indicating the existing gap or problems in the field & Step 2a: Stating the purpose of the study \\
Step 2: Stating the purpose of the study & Step 2b: Claiming significance of the study \\
Move 3: Methodology & Move 3: Methodology \\
Move 4: Results and Conclusion & Move 4: Contribution \\
Step 1: Reporting the major results, findings, arguments or & Step 1: Reporting the major results, findings, arguments or \\
conclusions of the study & conclusions of the study \\
Step 2: suggestions for further study & Step 2: Further implications, extensions or suggestions for \\
& further study \\
\hline
\end{tabular}

\section{List of the selected legal RA abstracts:}

English:

Aaron Tang. Life After Janus. Columbia Law Review. 2019 (119): 677-761.

Andrew Kent, Ethan J. Leib \& Jed Handelsman Shugerman. Faithful Execution and Article II. Harvard Law Review. 2019 (132): 2111-2192.

Andrew Verstein. The Jurisprudence of Mixed Motives. The Yale Law Journal. 2018 (127): 1106-1175.

Barton Beebe \& Jeanne C. Fromer. Are We Running out of Trademarks? An Empirical Study of Trademark Depletion and Congestion. Harvard Law Review. 2018 (131):943-1045.

Brian D. Feinstein \& Daniel J. Hemel. Partisan Balance with Bite. Columbia Law Review. 2018 (118): 9-82.

Cass R. Sunstein \& Adrian Vermeule. The Morality of Administrative Law. Harvard Law Review. 2018 (131): 1932-1978.

Daniel J. Hemel \& Lisa Larrimore Ouellette. Innovation Policy Pluralism. The Yale Law Journal. 2019 (128): 544-614.

Deenis Chu. Broker-Dealers for Virtual Currency: Regulating Cryptocurrency Wallets and Exchanges. Columbia Law Review. 2018 (118): 2323-2360.

Fiona Scott Morton \& Hebrert Hovenkamp. Horizontal Shareholding and Antitrust Policy. The Yale Law Journal. 2018 (127): 2026-2047.

Hebrert Hovenkamp \& Carl Shapiro. Horizontal Mergers, Market Structure, and Burdens of Proof. The Yale Law Journal. 2018 (127): 1996-2025.

Howard Shelanski. Antirust and Deregulation. The Yale Law Journal. 2018 (127): 1922-1960.

Jennifer Nou \& Edward H. Stiglits. Regulatory Bundling. The Yale Law Journal. 2019 (128): 1174-1245.

Joseph Blocher. Free Speech and Justified True Belief. Harvard Law Review. 2019 (133):440-496.

Joseph Landau. Process Scrutiny: Motivational Inquiry and Constitutional Rights. Columbia Law Review. 2019 (119): $2147-.2204$

Joseph P. Fishman. Music as a Matter of Law. Harvard Law Review. 2018 (131): 1863-1923.

Kate Klonick. The New Governors: The People, Rules, and Processes Governing Online Speech. Harvard Law Review. 2018 (131): 1598-1670.

Lina M. Khan \& David E. Pozen. A Skeptical View of Information Fiduciaries. Harvard Law Review. 2019 (133): 498-540.

Lina M. Khan. The Separation of Platforms and Commerce. Columbia Law Review. 2019 (119):973-1098.

Lucian Bebchuk \& Scott Hirst. Index Funds and the Future of Corporate Governance: Theory, Evidence, and Policy. Columbia Law Review. 2019 (119): 2029-2146.

Luke Ali Budiardjo. The Effect of Arbitration Agreements on the America Invents Act's Inter Partes Review Procedure. Columbia Law Review. 2018 (118): 83-126.

Matteo Godi. Beyond Nudging: Debiasing Consumers Through Mixed Framing. The Yale Law Journal. 2019 (128): $2034-2086$.

Melissa J. Durkee. International Lobbying Law. The Yale Law Journal. 2018 (127): 1742-1826.

Natasha Sarin. Making Consumer Finance Work. Columbia Law Review. 2019 (119): 1519-1596.

Nick Werle. Prosecuting Corporate Crime when Firms Are Too Big to Jail: Investigation, Deterrence, and Judicial Review. The Yale Law Journal. 2019 (128):1366-1438.

Robin Bradley Kar \& Margaret Jane Radin. Psuedo-Contract and Shared Meaning Analysis. Harvard Law Review. 2019 (132): 1138-1219.

Saikrishna Bangalore Prakash. Of Synchronicity and Supreme Law. Harvard Law Review. 2019 (132): 1221-1299.

Shaanan Cohney, David Hoffman, Jeremy Sklaroff \& David Wishnick. Coin-Operated Capitalism. Columbia Law Review. 2019 (119): 591-676.

Shelley Welton. Electricity Market and the Social Project of Decarbonization. Columbia Law Review. 2018 (118):1067-1138.

Steven C. Salop. Invigorating Vertical Merger Enforcement. The Yale Law Journal. 2018 (127): 1962-1994.

Suresh Naidu, Eric A. Posner \& Glen Weyl. Antitrust Remedies for Labor Market Power. Harvard Law Review. 2018 (132): $549-601$.

Chinese:

陈小君. 宅基地使用权的制度困局与破解之维[J].法学研究, 2019(3) : 48-72.

冯彦君. 劳动法上“合理”的多重意蕴及其应用[J]. 中国法学, 2018(5) : 181-197.

高富平. 个人信息保护: 从个人控制到社会控制[J].法学研究, 2018(3) : 84-101.

侯利阳. 市场与政府关系的法学解构[J]. 中国法学, 2019(1) : 186-203.

蒋舸. 《反不正当竞争法》网络条款的反思与解释一以类型化原理为中心 [J]. 中外法学, 2019(1) : 180-202.

姜涛. 网络型诈骗罪的拟制处分行为[J]. 中外法学, 2019(3):692-712.

李吴,王文娜. 婚姻缔结行为的效力瑕疪一兼评民法典婚姻家庭编草案的相关规定 [J].法学研究, 2019(4) : 102-118. 
黎四奇. 二维码扫码支付法律问题解构[J]. 中国法学, 2018(3): 110-131.

刘冰. 论我国破产制度的构建 $[\mathrm{J}]$. 中国法学, 2019(4):223-243.

刘征峰. 家庭法中的类型法定原则一基于规范与生活事实的分离和整合视角 [J]. 中外法学, 2018(2) : 472-492.

刘庄. 影子银行的第三类风险 [J]. 中外法学, 2018(1) : 194-207.

陆青. 离婚协议中的“赠与子女财产”条款研究[J].法学研究, 2018(1) : 87-105.

吕忠梅. 民法典“绿色化”与环境法典的调适[J]. 中外法学, 2018(4) : 862-882.

彭錞. 公共企事业单位信息公开:现实、理想与路径[J]. 中国法学, 2018(6) : 89-108.

彭岳. 分享经济规制现状及方法改进[J]. 中外法学, 2018(3) : 763-781.

彭岳. 一致性解释原则在国际贸易行政案件中的适用[J].法学研究, 2019(1) : 193-208.

阮开欣. 涉外知识产权归属的法律适用[J].法学研究, 2019(5) : 191-208.

邵六益. 审委会与合议庭：司法判决中的隐匿对话[J]. 中外法学, 2019(3) : 713-738.

王道. 发电子商务平台经营者安保责任研究[J]. 中国法学, 2019(6) : 282-300.

王䒯. 诈骗罪重构:交易信息操纵理论之提倡[J]. 中国法学, 2019(3) : 240-260.

徐汉明. 我国网络法治的经验与启示 [J]. 中国法学, 2018(3) : 51-70.

徐阳光. 破产程序中的税法问题研究[J]. 中国法学, 2018(2) : 208-227.

许德风. 公司融资语境下股与债的界分 [J].法学研究, 2019(2) : 77-97.

余凌云. 警察权的“脱警察化”规律分析[J]. 中外法学，2018(2):393-413.

张新宝. 《民法总则》个人信息保护条文研究 [J]. 中外法学, 2019(1) : 54-75.

章凯业. 商标保护与市场竞争关系之反思与修正 [J].法学研究, 2018(6) : 92-108.

郑观. 个人信息对价化及其基本制度构建 $[J]$. 中外法学, 2019(3) : 477-498.

庄加园. 动产抵押的登记对抗原理[J].法学研究, 2018(5):76-94.

朱芒. 高校校规的法律属性研究[J]. 中国法学, 2018(4) : 140-159.

左卫民. 迈向大数据法律研究[J].法学研究, 2018(4) : 139-150.

\section{ACKNOWLEDGMENTS}

The current work is supported by the grant 21SKGH004 from Chongqing Municipal Education Commission.

\section{REFERENCES}

[1] Agathopoulou, E. (2009). Characteristics of high-rated and low-rated conference abstracts: a genre-based analysis. In K. Katsaboxaki-Hodgets (ed.), Proceedings of the International Conference Options and Practices of LSP. University of Crete. Crete: Crete University Press:150-70.

[2] Alhuqbani, M.N. (2013). Genre-based analysis of Arabic research article abstracts across four disciplines. Journal of Educational and Social Research, 3(3): 371-382.

[3] Bazerman, C. (1984). Modern Evolution of the Experimental Report in Physics: Spectroscopic Articles in Physical Review, 1893-1980. Social Studies of Science, 14(2): 163-196.

[4] Berkenkotter, C., \& Huckin, T. N. (1995). Genre Knowledge in Disciplinary Communication: Cognition/culture/power. Hillsdale, NJ, L. Erlbaum Associates.

[5] Bhatia, V. K. (1993). Analyzing Genre: Language Use in professional settings. London: Longman.

[6] Bhatia, V. K. (2004). Worlds of Witten Discourse: A Genre-based View. London: Continuum.

[7] Bhatia, V. K. (2008). Towards critical genre analysis. London: Routledge.

[8] van Bonn, S., \& Swales, J. M. (2007). English and French journal abstracts in the language sciences: Three exploratory studies. Journal of English for Academic Purposes, 6(2): 93-108.

[9] Cao, Y., \& Xiao, R. (2013). A multi-dimensional contrastive study of English abstracts by native and non-native writers. Corpora, 8(2): 209-234.

[10] Cavalieri, S. (2014). Variation across disciplines. The case of applied linguistics and medicine. In M. Bondi, \& R. Lorés Sanz (Eds.), Abstracts in academic discourse: Variation and change, Bern. Germany: Peter Lang: 161-174.

[11] Cross, C., \& Oppenheim, C. (2006). A genre analysis of scientific abstracts, Journal of Documentation, 62(4):428-446.

[12] Chu, J. W., \& Jiang, Y. (2018). A corpus-based study of engagement resources in English abstracts of medical research articles by Chinese and Native English authors. Medical Education Research and Practice, 26(1): 134-139.

[13] Diani, G. (2014). On English and Italian research article abstracts: Genre variation across cultures. In M. Bondi, \& R. Lorés Sanz (Eds.), Abstracts in academic discourse: Variation and change, Bern. Germany: Peter Lang: 65-83

[14] Doró, K. (2013). The rhetoric structure of research article abstracts in English studies journals. Prague Journal of English Studies, 2 (1): 119-139.

[15] Fairclough, N. (1995). Critical discourse analysis: A critical study of language. London: Longman.

[16] Ghasempour, B., \& Farnia, M. (2017). Contrastive move analysis: Persian and English research articles abstracts in law. The Journal of Teaching English for Specific and Academic Purposes, 5(4): 739-753.

[17] Halliday, M.A.K. (1978). Language as Social Semiotic: The Social Interpretation of Language and Meaning. Edward Arnold, London.

[18] Halliday, M. (1994). An Introduction to Functional Grammar (2nd ed.). New York: Oxford University Press.

[19] Hartley, J. (2003). Improving the clarity of journal abstracts in psychology: The case for structure. Science Communication, 24 (3): 366-379.

[20] Hasan, R. (1977). Text in the Systemic-Functional Model. In W. Dressler (ed.) Current Trends in Text Linguistics. 228-246, 
Berlin: Walter de Gruyter.

[21] Hatzitheodorou, A.-M. (2014). A genre-oriented analysis of research article: Abstracts in law and business journals. In M. Bondi, \& R. Lores Sanz (Eds.), Abstracts in academic discourse: Variation and change. Bern, Germany: Peter Lang: 175-198.

[22] Hyland, K. (2000). Disciplinary discourses: Social interactions in academic writing. London: Longman.

[23] Hyland, K. (2004). Genre and second language writing. Ann Arbor, MI: University of Michigan.

[24] Kanoksilapatham, B. (2005). Rhetorical structure of biochemistry research articles. English for Specific Purposes, 24 (3): 269-292.

[25] Lewin, B.A., Fine, J., \& Young, L. (2001). Expository Discourse: A Genre-Based Approach to Social Science Research Texts. London and New York: Continuum.

[26] Lorés, R. (2004). On RA abstracts: From rhetorical structure to thematic organization. English for Specific Purposes, 23(3): 280-302.

[27] Majid, T. G., \& Omid, T. (2018). A structural move analysis of the abstract section of ISI articles of Iranian and native scholars in the field of agricultural engineering. International Journal of Research Studies in Language Learning, 7(3): 109-122.

[28] Marefat, H., \& Mohammadzadeh, S. (2013). Genre analysis of literature research article abstracts: A cross-linguistic, cross-cultural study. Applied Research on English Language, 2(2): 37-50.

[29] Martin. J. R. (1992). English Text: System and structure. Amsterdam: John Benjamins.

[30] Martín-Martín, P. (2003). A genre analysis of English and Spanish research paper abstracts in experimental social sciences. English for Specific Purposes, 22(1): 25-43.

[31] Miller, C.R. (1984). Genre as social action. Quarterly Journal of Speech, 70(2): 151-167.

[32] Nwogu, K. N. (1991). The structure of science popularizations: A genre-analysis approach to the schema of popularized medical texts. English for Specific Purposes, 10(2): 111-123.

[33] Pho, P. D. (2008). Research article abstracts in applied linguistics and educational technology: A study of linguistic realizations of rhetorical structure and authorial stance. Discourse Studies, 10(2): 231-250.

[34] Saboori, F., \& Hashemi, M.R. (2013). A cross-disciplinary move analysis of research article abstracts. International Journal of Language learning and Applied Linguistics World, 4 (4): 483-496.

[35] Salager-Meyer, F. (1990). Discoursal flaws in medical English abstracts: a genre analysis per research- and text- type. TEXT, 10(4): 365-384.

[36] Salager-Meyer, F. (1992). A text-type and move analysis study of verb tense and modality distribution in medical English abstracts. English for Specific Purposes, 11(2): 93-113.

[37] Santos, M. B. D. (1996). The textual organization of research paper abstracts in applied linguistics. TEXT, 16(4): 481-499.

[38] Santos, V. B. M. P. D. (2002). Genre analysis of business letters of negotiation. English for Specific Purposes, 21(2): 167-199.

[39] Stotesbury, H. (2003). Evaluation in research article abstracts in the narrative and hard sciences. Journal of English for Academic Purposes, 2(4): 327-341.

[40] Swales, J. M. (1990). Genre analysis: English in academic and research settings. Cambridge: Cambridge University Press.

[41] Swales, J. M., \& Feak, C. B. (2009). Abstracts and the writing of abstracts. Ann Arbor, MI: University of Michigan Press.

[42] Tankó, G. (2017). Literary research article abstracts: An analysis of rhetorical moves and their linguistic realizations. Journal of English for Academic Purposes, (27), 42-55.

[43] Tseng, F. (2011). Analysis of move structure and verb tense of research article abstracts in applied linguistics. International Journal of English Linguistics, 1 (2): 27-35.

[44] Van Dijk, T. A. (1980). Macrostructures: An interdisciplinary study of global structures in discourse, interaction, and cognition. Hillsdale, NJ: Erlbaum.

[45] Zhao, Y. Q., Liu, L. D., Deng Y. C. et. al. (2019). The move-step analysis of international literary research article abstracts. Foreign Languages Research, 173 (1): 18-23.

Jing Duan was born in Chongqing, China in 1989. She received her master degree in English linguistics from Southwest University, China in 2013.

She is currently a lecturer in the School of Foreign Languages, Southwest University of Political Science and Law, Chongqing,

China. Her research interests include functional linguistics, genre analysis, ESP, EAP and legal translation. Her publications include:

Translated book: Big Law (Chinese version), Beijing: Law Press China, 2017.

Research paper: A Comparative Study of Metadiscoursal Features in English Research Articles Abstracts in Hard Disciplines. Second author. Applied Research on English Language. 2018 (Volume 7).

Jing Wei was born in Chongqing, China in 1979. She received her PH.D. degree in applied linguistics from Southwest University, China in 2014.

She is currently an associate professor in the College of International Studies, Southwest University, Chongqing, China. Her research interests include EFL writing, Functional Linguistics and English for academic purposes. She has published several research papers including: Thematic choice in Chinese college students' English essays. English for Specific Purposes. Volume 41, Issue 1, 2016; Corpus-based research on topical Theme choices in Chinese and Swedish English learners' English writings. Theory and Practice in Language Studies, Volume 3, Issue 12, 2013. 